Check for updates

London, UK

2 Nuffield Department of Primary Care Health Sciences, University of Oxford, Oxford, UK

Correspondence to M Gill mgilm1@gmail.com Cite this as: BMJ2020;371:m4436 http://dx.doi.org/10.1136/bmj.m4436 Published: 16 November 2020

\section{Mass testing for covid-19 in the UK}

\author{
An unevaluated, underdesigned, and costly mess
}

Mike Gill, ${ }^{1}$ Muir Gray ${ }^{2}$

Quick turnaround testing for covid-19 is to be made available to everybody, initially to those without symptoms, across England at a cost of £1oobn (€110bn; \$13obn). ${ }^{1}$ This follows a still uncompleted "pilot" in Liverpool, which started on 6 November at the invitation of Liverpool City Council in October, after incidence had peaked. The objective is "to demonstrate that massive asymptomatic testing can help identify far more cases and break the chain of transmission of coronavirus." 2

Participation in this pilot is voluntary. There is no call or recall. All participants receive two tests, the standard PCR test and the rapid turnaround (within 1 hour) lateral flow Innova test. Those with a positive result in either test are asked to self-isolate and are registered with the national track and trace programme, which initiates contact tracing. Key workers, health and social care staff, school staff, and children aged 11 and over are being targeted, but anyone can get tested, preferably at least twice within two weeks.

This is a screening programme, not opportunistic case finding: people are invited to have a test they would not otherwise have had, or asked for. If judged against the criteria drawn up by the UK's National Screening Committee for appraisal of a programme's viability, effectiveness, and appropriateness, ${ }^{3}$ it does not do well and has been already roundly criticised. ${ }^{4}$

Many asymptomatic people testing positive for covid-19 are probably relatively uninfectious. ${ }^{5}$ Evidence suggests at least a half may develop symptoms ${ }^{6}$ requiring self-isolation without the need for a test. Since few currently adhere to self-isolation, ${ }^{7}$ this is an obvious area for improvement before we embark on an expensive screening programme. Without a systematic approach to call and recall, those most at risk of being infected and transmitting may be least likely to present for screening. ${ }^{8}$

\section{Potential harms}

Despite claims by the city council that the Innova test is "very accurate with high sensitivity and specificity," ${ }^{2}$ it has not been evaluated in these conditions. The test's instructions for use state that it should not be used on asymptomatic people. A preliminary evaluation from Porton Down and Oxford University ${ }^{9}$ throws little light on its performance in asymptomatic people or in the field. It suggests the test misses between one in two and one in four cases. The false positive rate of $0.6 \%$ means that at the current prevalence in Liverpool, for every person found truly positive, at least one other may be wrongly required to self-isolate. As prevalence drops, this will become much worse.
The self-isolation and tracing of contacts triggered by a positive result can of course be seen as benefiting the individual and others, such as household members. But we know self-isolation has a regressive effect: income level influences adherence to self-isolation ${ }^{10}$ and the likelihood of household transmission. ${ }^{11}$ This underlines the importance of reducing the rate of false positive results and providing appropriate support-financial, psychological, and material-to people who must isolate.

Evidence that this pilot will reduce transmission is not yet established. This makes it even more critical that it is carefully planned; the different components, including testing centres, contact tracing, laboratories, and primary care contributions, are quality assured; its total resource requirements identified and costed; and the pilot evaluated for cost effectiveness.

\section{Shaky ground}

With incidence across Liverpool already falling, attributing and quantifying any additional effect from the programme may prove complex. Instead, similar programmes are being rolled out across the country to universities and local authorities even before this pilot is complete.

The queues of people seeking tests in Liverpool suggest the initial acceptability of this pilot is high, at least to some. Its ethical basis, however, looks shaky. The council claims, wrongly, that the test detects infectiousness and is accurate. In fact, if used alone it will lead to many incorrect results with potentially substantial consequences. The context for gaining consent has been tarnished by the enthusiasm of some local officials and politicians. In the case of schools, the programme has been culpably rushed: parents have had to respond unreasonably promptly to a request to opt out if they do not want their child screened. ${ }^{12}$

There is no protocol for this pilot in the public domain, let alone systems specification or ethical approval. The public has had no chance to contribute, as required by the UK standards for public involvement in research. ${ }^{13}$

Spending the equivalent of $77 \%$ of the NHS annual revenue budget on an unevaluated underdesigned national programme leading to a regressive, insufficiently supported intervention-in many cases for the wrong people-cannot be defended. The experience of the National Screening Committee and National Institute for Health Research (NIHR) tells us that allowing testing programmes to drift into use without the right system in place leads to a mess, and the more resources invested the bigger the mess. This 
system should be designed with up to 10 clear objectives to deliver the aim of reducing the impact of covid-for example, to identify cases more quickly or to mitigate the effects of deprivation on risk of infection and poor outcomes. Progress in each objective (or lack of it) should be measured against explicit criteria. Screening programmes based on experience and on the literature relating to complex adaptive systems ${ }^{14}$ offer a model for rapid progress.

At a minimum, there should be an immediate pause, until the fundamental building blocks of this mass testing programme have been externally and independently scrutinised by the National Screening Committee and NIHR. In the meantime, nobody's freedom or behaviour should be made contingent on having had a novel rapid test. It is premature to offer testing as the route to individuals' release from restrictions. Instead we must heed the advice of the World Health Organization and the government's Scientific Advisory Group for Emergencies (SAGE), radically improve the woeful performance of the "find, test, trace, and isolate" system, and renew the focus on identifying symptomatic people, especially among those sections of society most at risk. The current approach will open Pandora's box.

Competing interests: We have read and understood BMJ policy on declaration of interests and have no relevant interests to declare.

Provenance and peer review: Commissioned; not externally peer reviewed.

1 lacobucci G, Coombes R. Covid-19: government plans to spend f100bn on expanding testing to 10 million a day. BMJ 2020;370:m3520. doi: 10.1136/bmj.m3520 pmid: 32907851

2 Liverpool City Council. Mass testing FAQs (accessed 11 Nov 2020). https://iverpool.gov.uk/communities-and-safety/emergency-planning/coronavirus/how-to-get-tested/mass-testing-faqs/ accessed 11/11/20.

3 Public Health England. Criteria for appraising the viability, effectiveness and appropriateness of a screening programme. 2015. https://www.gov.uk/government/publications/evidence-reviewcriteria-national-screening-programmes/criteria-for-appraising-the-viability-effectiveness-andappropriateness-of-a-screening-programme.

4 Raffle A. Screening the healthy population for covid-19 is of unknown value, but is being introduced nationwide. BMJ Opinion, 9 Nov 2020. https://blogs.bmj.com/bmi/2020/11/09/screening-thehealthy-population-for-covid-19-is-of-unknown-value-but-is-being-introduced-nationwide/

5 WHO. Transmission of COVID-19 by asymptomatic cases. http://www.emro.who.int/health-topics/corona-virus/transmission-of-covid-19-by-asymptomatic-cases.html\#: :text=Available\%20evidence\%20from\%20contact\%20tracing,transmission\%20of\%20the\%20virus

6 He J, Guo Y, Mao R, Zhang J. Proportion of asymptomatic coronavirus disease 2019: a systematic review and meta-analysis. J Med Virol 2020. doi: 10.1002/jmv.26326 pmid: 32691881

7 Smith L, Potts HWW, Amlot R, etal. Adherence to the test, trace and isolate system: results from a time series of 21 nationally representative surveys in the UK (the COVID-19 Rapid Survey of Adherence to Interventions and Responses [CORSAIR] study).medRxiv2020. [Preprint.] https://www.medrxiv.org/content/10.1101/2020.09.15.20191957v1.full.pdf

8 Hart JT. The inverse care law. Lancet 1971;1:405-12 doi: 10.1016/S0140-6736(71)92410-X pmid: 4100731

9 Preliminary report from the Joint PHE Porton Down \& University of Oxford SARS-CoV-2 test development and validation cell: rapid evaluation of lateral flow viral antigen detection devices (LFDs) for mass community testing. 8 Nov 2020. https:/www.ox.ac.uk/sites/files/oxford/media_wysiwyg/UK\%20evaluation_PHE\%20Porton\%20Down\%20\%20University\%20of\%200xford_final.pdf

10 Waugh P. NHS test and trace chief admits workers fear "financial" hit if they self-isolate. Huffington Post 2020 Nov 7. https://www.huffingtonpost.co.uk/entry/dido-harding-self-isolation-financialworry_uk_5f036a9cc5b612083c5ffc8d?ncid=other_huffpostre_pqylmel2bk8\&utm_campaign=related_articles\&guce_referrer=aHROcHM6Ly9ibG9ncy5sc2UuYWMudWsv\&guce_referrer_sig=AQAAAGjUJEj7iTmbyTL7F55sleFEZJUGcD4Zs9osMFstHe_Hu7M-\&_guc_consent_skip=1605190198.

11 Haroon S, Chandan JS, Middleton J, Cheng KK. Covid-19: breaking the chain of household transmission. BMJ 2020;370:m3181. doi: 10.1136/bmj.m3181 pmid: 32816710

12 Jones RAK. Is the Liverpool Sars-Cov-2 screening project a true pilot study or the start of mass screening? [Electronic response to lacobucci G. BMJ 2020;371:m4268.] BMJ 2020. https://www.bmj.com/content/371/bmj.m4268/rapid-responses

13 UK Standards for Public Involvement. Setting the scene. https://sites.google.com/nihr.ac.uk/pistandards/standards/setting-the-scene\#h.p_1bDA7s6A2WhH

14 Gray M. Population healthcare: designing population-based systems. J R Soc Med 2017;110:183-7doi: 10.1177/0141076817703028.
This article is made freely available for use in accordance with BMJ's website terms and conditions for the duration of the covid-19 pandemic or until otherwise determined by BMJ. You may use, download and print the article for any lawful, non-commercial purpose (including text and data mining) provided that all copyright notices and trade marks are retained. 